\title{
New discoveries of the oldest trilobites Profallotaspis and Nevadella in the northeastern Siberian Platform, Russia
}

\author{
EVgeny BushueV, IRINA GoryaeVA \& VAdim Pereladov
}

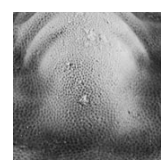

\begin{abstract}
Possibly the most ancient trilobites on the Siberian platform, belonging to the the Superfamily Fallotaspidoidea, were collected $36 \mathrm{~m}$ above the base of the middle Tyusser Formation, traditional lower Cambrian (Global Stage 3), in the Ulakhan-Aldyarkhai Creek section on the northern edge of the Cambrian Yudoma-Olenek sedimentary basin. These trilobite remains are probably slightly older that the first occurence of Profallotaspis jakutensis Repina, 1965 at other localities. Profallotaspis tyusserica sp. nov., although an olenellid, is characterised, among other features, by the "facial lines" that are possible incipient facial sutures, present anteriorly of ocular lobes and crossing the anterior margin of the cephalon. The occurrence of Profallotaspis tyusserica sp. nov. in the section is referred to the Profallotaspis Zone. The trilobites from the Pagetiellus anabarus-Nevadella Zone of the Cambrian Stage 3 were found $14.2 \mathrm{~m}$ above the FAD of Profallotaspis. - Key words: Fallotaspididae, Profallotaspis, Nevadella, Paranevadella, trilobites, Cambrian Stage 3, Siberian Platform.
\end{abstract}

Bushuev, E., Goryaeva, I. \& Pereladov, V. 2014. New discoveries of the oldest trilobites Profallotaspis and Nevadella in the northeastern Siberian Platform, Russia. Bulletin of Geosciences 89(2), 347-364 (11 figures). Czech Geological Survey, Prague. ISSN 1214-1119. Manuscript received January 25, 2013; accepted in revised form March 3, 2014; published online March 24, 2014; issued May 19, 2014.

Evgeny Bushuev (corresponding author), Irina Goryaeva \& Vadim Pereladov, Siberian Research Institute of Geology, Geophysics and Mineral Resources, Krasny prospekt 67, Novosibirsk, Russia; bushuev@sniiggims.ru, cambrian@sniiggims.ru

Profallotaspis Repina, 1965 belongs to the Family Fallotaspididae Hupé, 1953, representatives of which are restricted to the traditional lower Cambrian (Global Stage 3) in many regions of the world, including North America, Siberia, northwestern Eurasia, Morocco, Spain and eastern Germany. Representatives of Profallotaspis have been recorded in the provisional Cambrian Stage 3 deposits of Siberia and, probably, also North America. Repina (1965) described two Profallotaspis species, P. jakutensis (the type species) and $P$. privica, from the Pestrotsvet Formation in the middle reaches of the Lena River (southeastern Siberian Platform), where she identified the Profallotaspis jakutensis Zone in the lower part of Cambrian Stage 3 (Repina in Khomentovskiy \& Repina 1965; Palmer \& Repina 1993). Profallotaspis privica was later found by Repina (in Repina \& Lutchinina 1981) also in the Emyaksin Formation of the Fomich River section (Anabar Region, northern Siberian Platform). In North America, Hollingsworth (2007) found Profallotaspis? sp. in the upper part of the Andrews Mountain Member, Campito Formation, Esmeralda County, Nevada, but the poor preservation of the specimens prevented confident assignment to this genus.
In 2011 we examined the Cambrian sections in the eastern flank of the Bulkur anticline in the lower reaches of the Lena River (Ulakhan-Aldyarkhai Creek, Kharaulakh area) in the northeast part of the Siberian Platform (Fig. 1). The Ulakhan-Aldyarkhai section (UA2) is located on the northern edge of the Cambrian Yudoma-Olenek marine paleobasin, in a shallow-water marginal zone of the open shelf with prevailing carbonate-siliciclastic sedimentation. The outcrop is situated on the east bank of the Lena River, $350 \mathrm{~m}$ upstream of the Ulakhan-Aldyarkhai Creek (Fig. 2); the GPS coordinates of the section are $71^{\circ} 34.828^{\prime} \mathrm{N}$, $127^{\circ} 20.396^{\prime}$ E. Mixed carbonate-siliciclastic rocks with a total stratigraphic thickness of more than $400 \mathrm{~m}$ were uncovered along the riverside, with exposures extending for more than $2 \mathrm{~km}$. These rocks ranged in age from the base of Fortunian Stage to the Drumian Stage. The strata of the undefined Cambrian Stages 3 and 4 were subdivided into the Tyusser and Sakten formations.

This section was previously investigated by Lazarenko \& Nikiforov (1962), Repina (1967) and Repina et al. (1974). The latter authors published descriptions and photographs of all of the faunal groups found here as well as a 


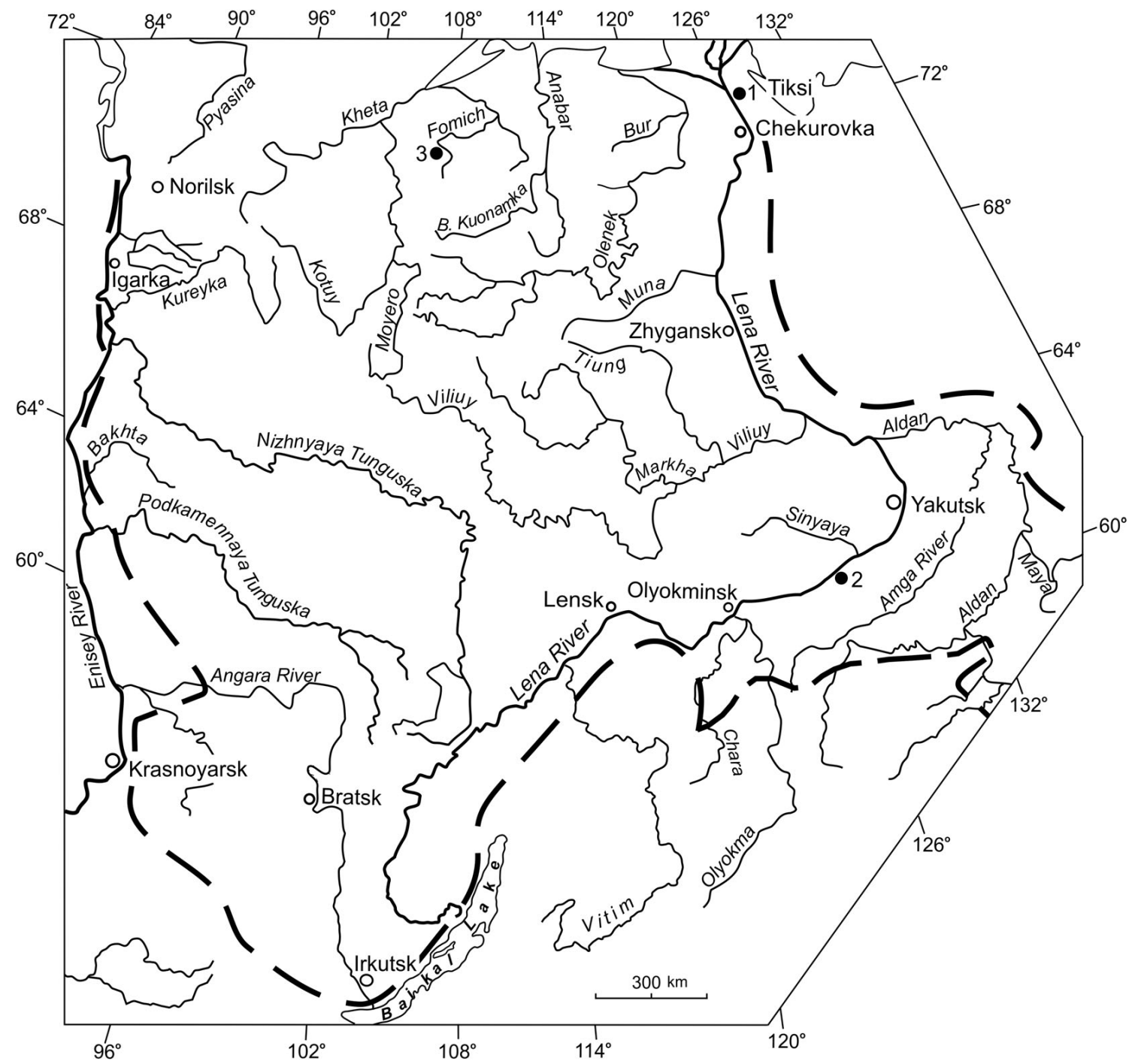

Figure 1. Location map of the Siberian Platform, showing the position of the reference sections. Numbers indicate the following sections: 1 - Ulakhan-Aldyarkhai section of the Tyusser Formation on the Lena River; 2 - sections of the Pestrotsvet Formation on middle reaches of the Lena River; 3 - section of the Emyaksin Formation on the Fomich River. Dotted line - the boundary of Siberian Platform.

biostratigraphic chart of the traditional lower Cambrian of the Kharaulakh area (Repina et al. 1974). The stratigraphically lowermost finding of a fragmentary trilobite cephalon from $44.3 \mathrm{~m}$ above the base of the Tyusser Formation, or $11.9 \mathrm{~m}$ below the base of the Nevadella Zone, was previously identified by Repina as Fallotaspidinae gen. indet. (Repina et al. 1974, p. 103, pl. 25, fig. 5).

\section{Geological setting}

The Tyusser Formation is characterized by a rather diverse lithology and is composed of three members informally designated as lower, middle and upper (Repina et al. 1974). The stratigraphic column presented herein compares the latest description of the section and stratigraphic investiga- tion of the Tyusser Formation with those given by Repina (Fig. 3). The lithologic description of the section, thickness of layers, and other features were specified and detailed by Vadim S. Pereladov during field studies in 2010 and 2011.

The lower member (units 1-5, $21.5 \mathrm{~m}$ thick) consists of quartz-feldspathic sandstones and conglomerates hosting dolerite sills. Very rare organic remains of archaeocyaths, hyoliths, tommotiids, and other small shelly fossils (SSF) occur in distinct lenses of limestone and dolomite sandstone.

The middle member (units 6-15, $35.3 \mathrm{~m}$ thick) is composed mainly of variegated, thinly laminated, clayey limestone, often brecciated and with interlayers of massive algal bioclastic limestones and calcareous siltstones. Organic remains are numerous and of diverse composition: SSF, archaeocyaths, brachiopods, trilobites, hyoliths, and acri- 


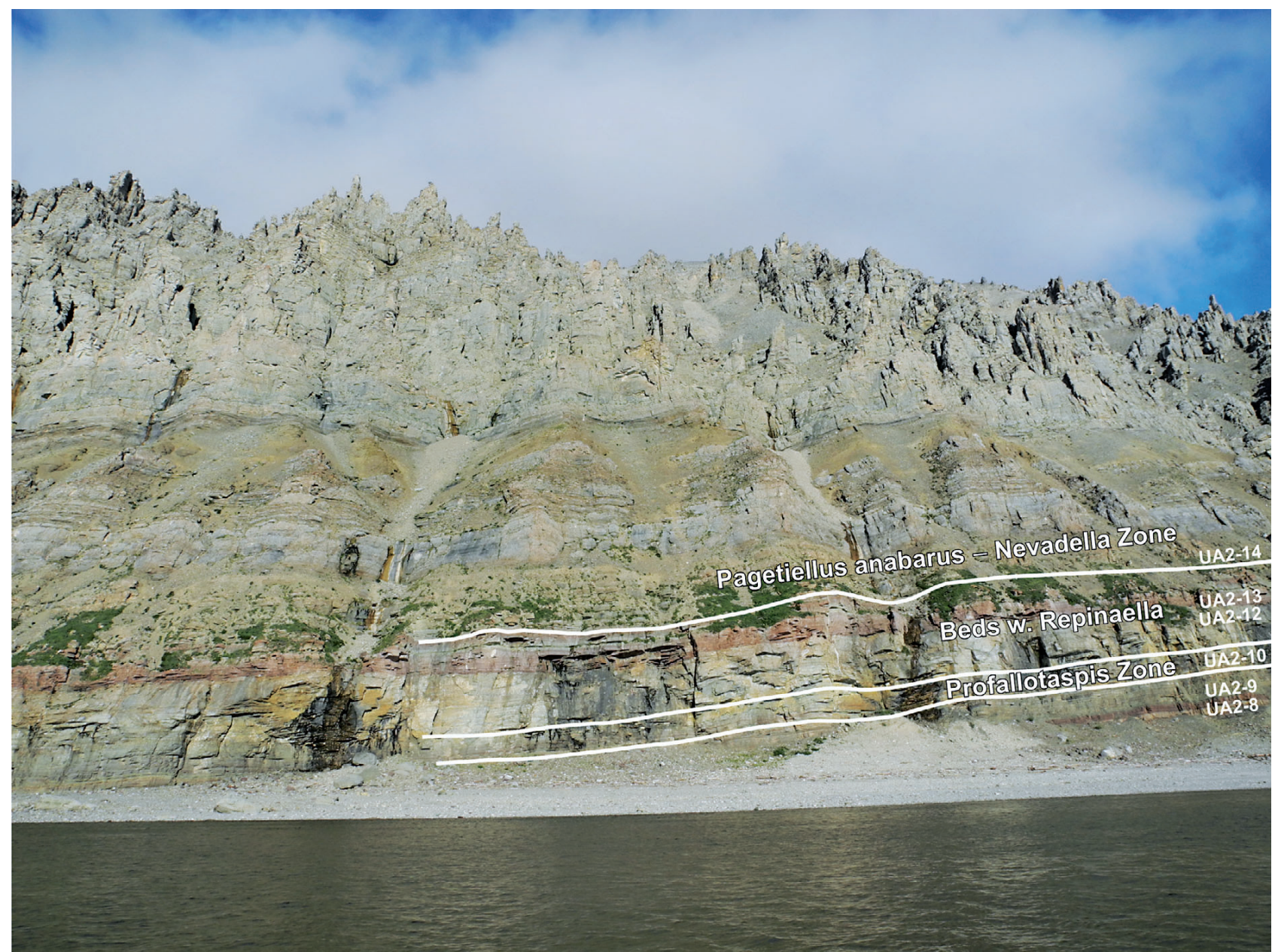

Figure 2. The Ulakhan-Aldyarkhai Section on the east bank of the Lena River with boundaries of the Profallotaspis and Pagetiellus anabarus-Nevadella zones in the middle member of the Tyusser Formation.

tarchs. In the section UA2, we discovered the lowest trilobites $36 \mathrm{~m}$ above the base of the Tyusser Formation, in a layer of compact pelitomorphic lenticular algal limestone with thin interbeds of bioclastic limestone (unit UA2-10, Fig. 4A). These trilobites are herein referred to the genus Profallotaspis. This occurrence of trilobites is located $8 \mathrm{~m}$ below the level of the first fallotaspidid trilobites discovered by Repina (see above). Several well-preserved cephala of Profallotaspis have recently been found at two levels in unit 10 (occ. UA2-10a, UA2-10d) at the top of small bioherms composed of compact algal limestone with Epiphyton (Fig. 4B). Inter-bioherm rocks are composed of calcareous siltstone to bafflestone containing Renalcis. The cephala are practically intact, and almost all parts are well-preserved, including sculpture. There are considerable morphological differences as compared to type species $P$. jakutensis Repina, and our specimens are assigned to the new species Profallotaspis tyusserica sp. nov (see systematic section below). Stratigraphically higher, $14.2 \mathrm{~m}$ above the level of Profallotaspis tyusserica sp. nov., we found trilobites of the Pagetiellus anabarus-Nevadella Zone: Pagetiellus pervulgatus Lazarenko, 1962, Pag. cf. anabarus Lazarenko, 1962, Pag. sakhaicus Nikiforov, 1974, Nevadella effusa Repina, 1974 and Paranevadella subgroenlandica (Repina, 1965). Large and small trilobite fragments occur throughout the whole unit 14, which is composed of bioturbated, finely laminated to platy, greenish-gray, fine-medium-grained limestones, with ruffled fibrous and thinly-wavy-laminated structure. The overlying bed is similar to unit 14 , but with a reddish-brown to purple in color, bioturbated, fine plated limestones. Bedding planes and near-surface layers are highly bioturbated. The lower third and upper part of the unit 15 contain remains of trilobites of the Pagetiellus anabarus-Nevadella Zone sensu Anonymous (1983).

Between the Profallotaspis Zone sensu Anonymous (1983) and the Pagetiellus anabarus-Nevadella Zone are $11.5 \mathrm{~m}$ of virtually trilobite-free strata, from which only fallotaspidid trilobite exoskeletal fragments (occurrence UA2-12a) were recovered in the top of a massive bed of 
archaeocyathan-algal limestone with bioherms. This layer is a characteristic marker bed in this and other sections of the Tyusser Formation in Kharaulakh area (Fig. 4B). We marked this interval as "Beds with Repinaella" because in 1962 a specimen of Repinaella explicata (Repina, 1974), see Repina et al. (1974, pl. 25, figs 1-4) was presumably found at the same stratigraphic level in the Tyusser Creek section (Fig. 3, occ. 334g).

The upper member of the Tyusser Formation is $70.5 \mathrm{~m}$ thick and is composed of gray and light-gray dolomitic, clay-rich and algal limestone with interlayers of calcareous sandstone. All rocks of the upper member contain numerous and diverse remains of trilobites, brachiopods and hyoliths. The base of the upper member of the Tyusser Formation corresponds with the base of unit 16, which is composed of algal bioclastic limestones, fine-medium grained limestones, medium-thickly-tabulated, with knobby bedding planes. Interbeds of greenish-gray, highly clayey thinly-tabulate limestones occur above this interval. Organic debris, unsorted in size, lies parallel to layering with patterned distribution. Abundant trilobites, hyoliths and brachiopods occur throughout the entire interval of the unit. The unit 16 belongs to the upper part of the Pagetiellus anabarus-Nevadella Zone. The overlying unit 17 of the upper member of Tyusser Formation belongs to the Judomia-Uktaspis Zone, which we do not discuss in this article. The base of the Judomia-Uktaspis Zone is defined by the lowest occurrence of the trilobite Judomia Lermontova (occurrence UA2-16i) in the section. The total thickness of the formation is $128 \mathrm{~m}$.

\section{Palaeoenvironment}

The lower part of the middle member (units 6-9) is interpreted as a shallow open marine setting with a predominance of storm facies, inferred normal salinity, with an estimated depth of about 15-20 m, and with a deepening-upward sequence. There are also signs of an alluvial cone (delta) and strong, possibly storm, currents. For example it is imbrication of clasts in conglomerates. Current marks and $\mathrm{V}$-shaped trenches in laid-down rocks (erosion contact) can be observed on silty sandstone surfaces. The middle and upper part of the member described of the Tyusser Formation (units 10-16) represents a carbonate facies of shoals, bars and reefs with archaeocyathan-algal buildups and bioherms of marginal zone in the open shelf. Perhaps, this sequence represents the early Cambrian outer organogenic reef along the northern edge of the YudomaOlenek Basin carbonate ramp. The presence of cosmopolitan genera of trilobites (Profallotaspis Repina, Nevadella Raw, Paranevadella Palmer \& Repina), together with lithological features discussed above indicates the open sea basin. All these sedimentary structures indicate that a rather lengthy Cambrian transgression started during the deposition of the Tyusser Formation.

\section{Correlations}

The newly documented FAD of Profallotaspis tyusserica sp. nov. in the Ulakhan-Aldyarkhai section of the Tyusser Formation is $8.1 \mathrm{~m}$ lower than the so far known first appearance of Repinaella explicata (Repina, 1965) and $13.5 \mathrm{~m}$ lower the first appearance of trilobites Paranevadella subgroenlandica (Repina, 1965) and Pagetiellus pervulgatus Lazarenko, 1962 (Fig. 3). Repinaella explicata is the characteristic species of the Repinaella (= Fallotaspis) Zone sensu Anonymous (1983) in the northern, northeastern and southeastern Siberian Platform (Astashkin et al. 1991). Paranevadella subgroenlandica and Pagetiellus pervulgatus are distributed in the overlying Pagetiellus anabarusNevadella Zone in the southeastern Siberian Platform. According to Repina (Repina in Khomentovskiy \& Repina 1965) the first appearance of Profallotaspis jakutensis Repina 1965, which is characteristic species of the Profallotaspis Zone, is $3 \mathrm{~m}$ lower than the FAD of Repinaella $\mathrm{sp}$. in the Isit outcrop of the Pestrotsvet Formation. In other sections of Cambrian Stage 3 rocks of the Pestrotsvet Formation in the middle reaches of the Lena River, P. jakutensis Repina occurs together with Repinaella explicata (Repina) and $R$. sibirica (Repina 1965), which are characteristic species of the Repinaella Zone. It may be concluded that Profallotaspis tyusserica sp. nov. appeared almost at the same time or a little earlier than $P$. jakutensis Rep.

As for global correlation, the relationship between biozones of the Cambrian Stage 3 of Laurentia, Siberia, Morocco etc. were conclusively and thoroughly shown by Hollingsworth (2011, p. 38). In his correlation diagram, onset of representative species Profallotaspis jakutensis Repina correlate with first appearance of Hupetina and Eofallotaspis from the Eofallotaspis Zone of Morocco and Profallotaspis? from the Fritzaspis Zone of Laurentia (North America). We agree with this interpretation and offer here a Cambrian Stage 3 correlation scheme of Siberia, Laurentia, Morocco, China, and Australia biozones. This scheme is based on the schemes of Hollingsworth (2011) and Yuan et al. (2011) together with our new data and alterations (Fig. 5). Data from Jell (Jell in Bengston et al. 1990; Jell 2003) and Pillola (1993) were also added in the correlation scheme. The first possible correlation level occurs at the base of the Profallotaspis Zone at the FADs of Profallotaspis tyusserica sp. nov. and P. jakutensis Repina which bear a significant resemblance to the earliest species of the Eofallotaspis Zone in Morocco E. prima Sdzuy, 1978 and also resemble Profallotaspis? and Amplifallotaspis keni Hollingsworth, 2007 from the Fritzaspis Zone of Laurentia. 


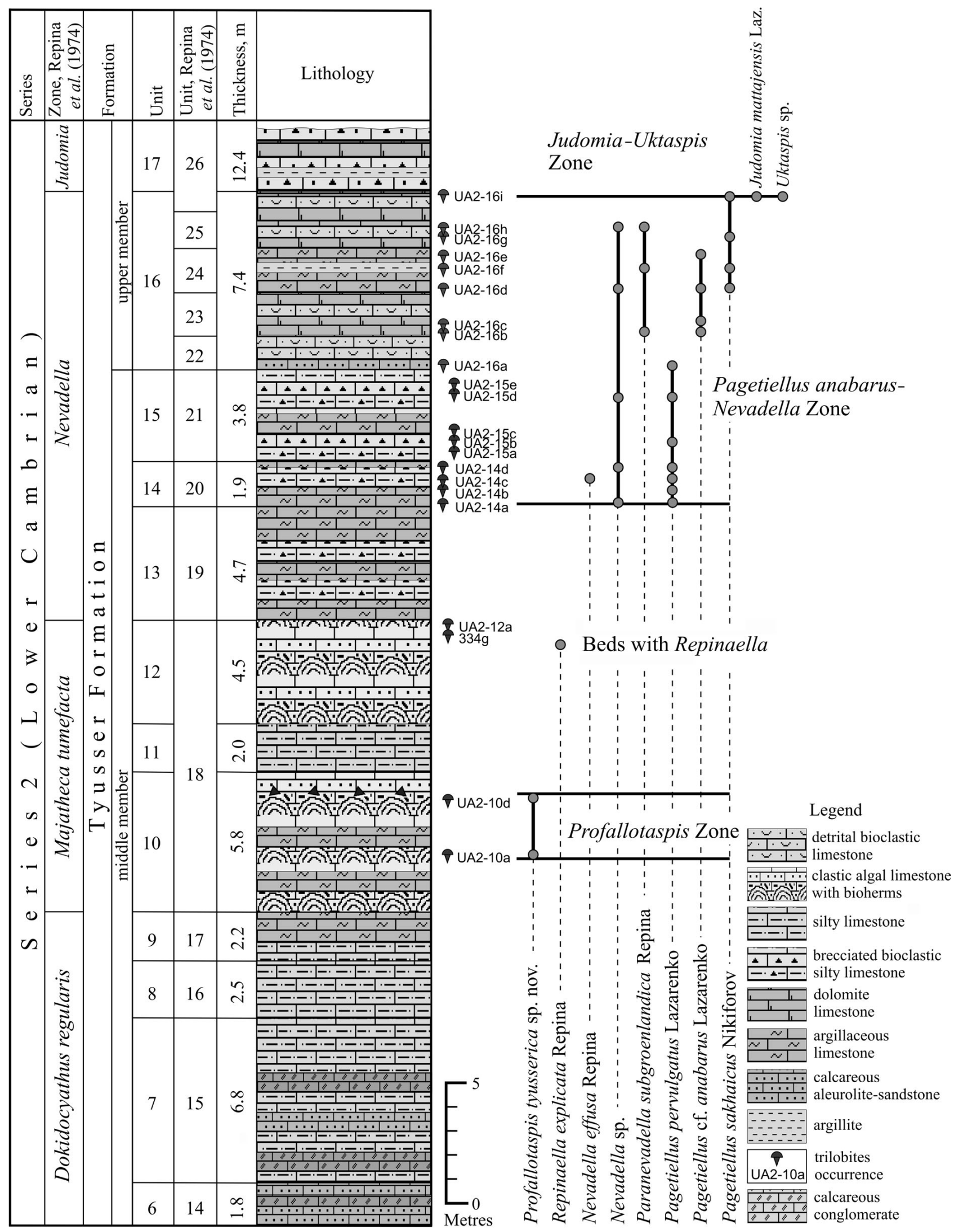

Figure 3. Stratigraphic distribution of trilobites from the middle part of the Tyusser Formation in the Ulakhan-Aldyarkhai section (UA2), the Lena River, northeastern Siberian Platform. 

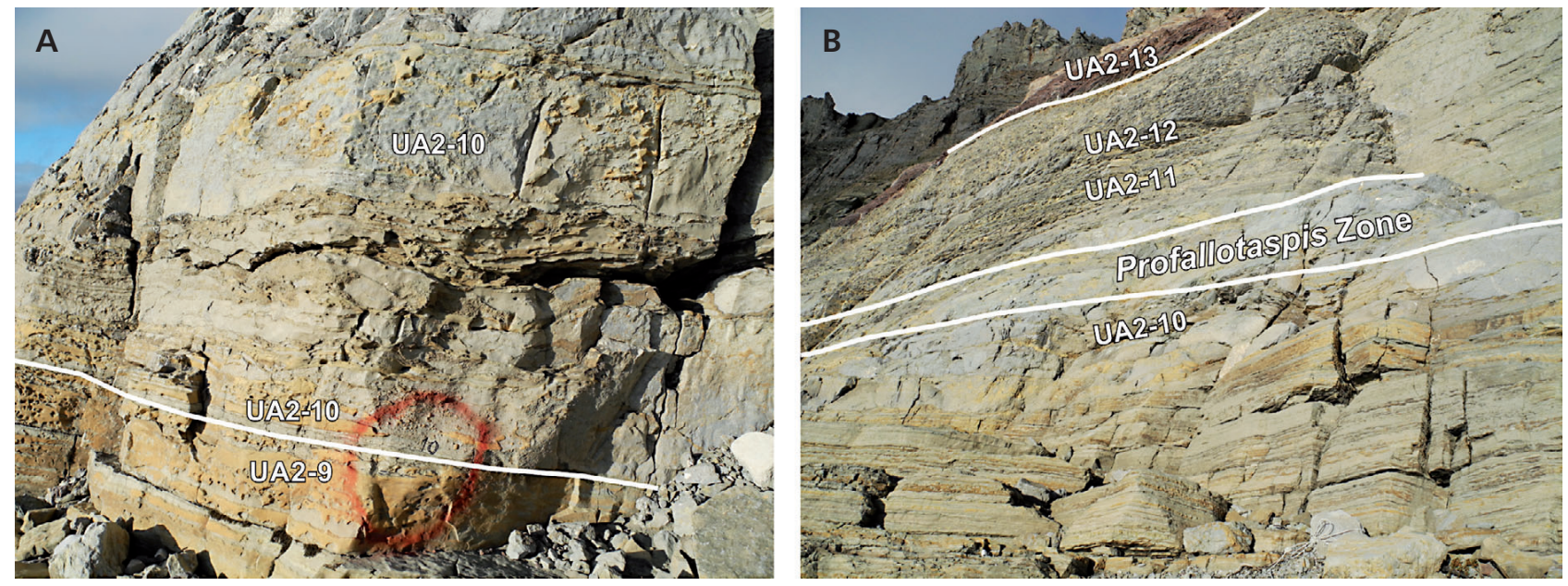

Figure 4. Photographs of the middle member of the Tyusser Formation. - A - the base of unit UA2-10: the bioherms are composed of compact algal limestone with Epiphyton. $\bullet$ B - the boundaries of the Profallotaspis Zone inside unit UA2-10 and the top layer of algal-archaeocyathan bioherm limestones (unit UA2-12).

Yuan et al. (2011) extensively discussed correlations of South China Cambrian Series 2 and have shown that the Parabadiella Zone in South China may be time-equivalent to the Eofallotaspis Zone in Morocco and the Profallotaspis Zone in Siberia. Also the Abadiella huoi Zone in Australia correlates with the Parabadiella Zone. The second possible correlation level occurs at the Repinaella Zone where Repinaella explicata (Repina, 1965), R. sibirica (Repina, 1965) and Bigotina malykanica Suvorova, 1960 appear. This level corresponds with the occurrence of Repinaella sp. in the Fritzaspis Zone of Laurentia and with the FAD of Bigotina bivallata Cobbold, 1935 in the Eofallotaspis Zone in Morocco (Pillola 1993). The following two correlation levels are Archaeaspis hupei Repina in Khomentovskiy \& Repina, 1965 and Paranevadella subgroenlandica (Repina, 1965) within the Pagetiellus anabarus-Nevadella Zone in Siberia. These two levels are possibly equivalent of the occurrence of Archaeaspis (s.s.) sp. at the base and Nevadia in the upper part of the Fallotaspis Zone in Laurentia. The base of the Judomia-Uktaspis Zone, which includes Judomia mattajensis Lazarenko, 1962 and Prouktaspis insolens (Suvorova, 1960), is crucial for the international correlation. This level corresponds to the upper part of the Fallotaspis Zone in Laurentia on occurrence of Judomia?; it also corresponds with the base of the Pararaia tatei Zone in Australia as for the occurrence of Prouktaspis luta Jell, 1990. In Australia and South China Eoredlichia shensiensis Zhang, 1966 occurs at the same level.

\section{Systematic palaeontology}

The terminology used in these descriptions follows Harrington (1959) and Palmer \& Repina (1993) (Fig. 6A). General dimensions of the cephalon are shown in Fig. 6B. In the descriptions, the length of the glabella does not include occipital ring.

Illustrated specimens are reposited in the Central Siberian Geology Museum (CSGM) of the Trofimuk Institute of Oil and Gas Geology and Geophysics of Siberian Branch of Russian Academy of Sciences (Novosibirsk), collection number 2046. Trilobite photographs were made by P.V. Fomin in the Department of Stratigraphy and Palaeontology.

Order Redlichiida Richter, 1932

Suborder Olenellina Walcott, 1890

Superfamily Fallotaspidoidea Hupé, 1953

Family Fallotaspididae Hupé, 1953

\section{Genus Profallotaspis Repina, 1965 in Khomentovskiy \& Repina (1965)}

Type species. - Profallotaspis jakutensis Repina, 1965 in Khomentovskiy \& Repina (1965), Cambrian Stage 3, the Pestrotsvet Formation, Lena River, southeastern Siberian Platform.

Profallotaspis tyusserica Bushuev \& Goryaeva sp. nov. Figures 7, 8A-H, 9A-H, 10A-C

Holotype. - Cephalon, CSGM, No. 2046/1, Novosibirsk; Fig. 8A-D.

Type horizon and locality. - Cambrian Stage 3, Tyusser Formation, Profallotaspis Zone. The Lena River, Ulakhan-Aldyarkhai Creek, Northeastern Siberian Platform, Russia.

Material. - Four well preserved paratype specimens CSGM No. 2046/1, 2046/2, 2046/3, 2046/4 from 4.4 m 


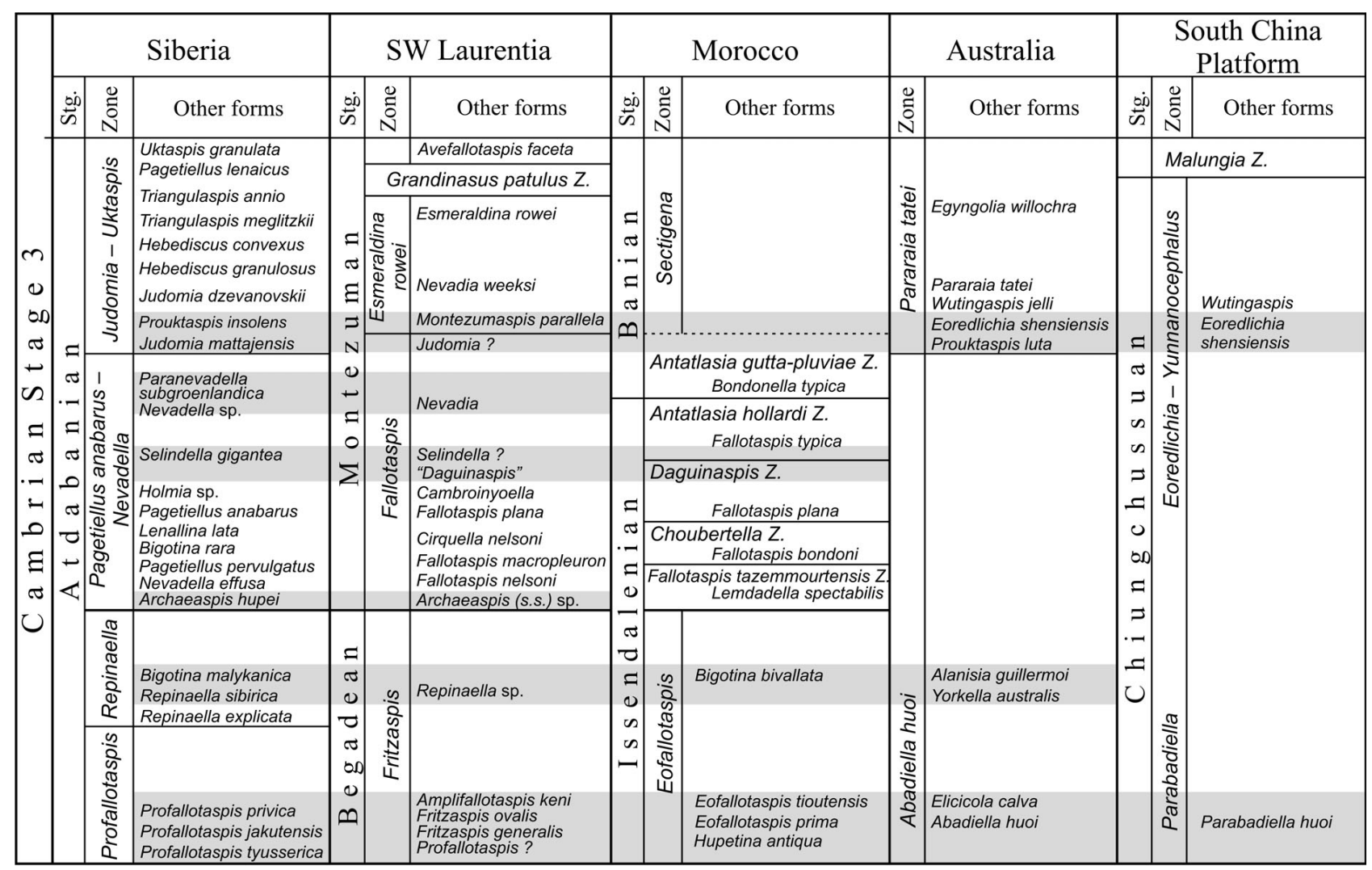

Figure 5. Correlation of the Cambrian Stage 3 between Siberia and other palaeocontinents. Shading indicates correlation levels.

above the base of the unit 10 and one moderately well preserved specimen $(2046 / 5)$ from $2.5 \mathrm{~m}$ above the base of the unit. The specimens occur at the top of small bioherms composed of compact algal limestone, pelitomorphic to fine-grained, grey, cloded with interbeds of clastic limestone. All specimens came from Ulakhan-Aldyarkhai section UA2, the middle member of the Tyusser Formation.

Etymology. - Named after the nearby Tyusser creek.

Diagnosis. - Cephalon moderately extended in width by 1.6 times its length, with gently curved anterior margin. Glabella moderately tapered forward, convex, with three pairs of glabellar furrows oriented obliquely backwards when traced adaxially (S1, S2, S3). Anterior border narrow (less than 0.1 of glabella length), flattened and tilted back. Occipital ring of rounded triangle outline, with moderately long, robust axial spine, rising upwards and backwards. Occipital furrow strongly curved back, deep, reaches axis. Distinct thin, paired, well-impressed "facial lines", which onset at the merging of the ocular lobe with the eye ridge and run obliquely forward on the extraocular area. Small intergenal spines located along the posterior margin at distinct intergenal angle. Medium length genal spines. Cephalic surface covered a system of raised ridges, intersecting to form a network of fine polygons with diameters up to $0.05 \mathrm{~mm}$.
Description. - Cephalon almost semicircular in outline; sagittal length ranges from 5.1 to $9.5 \mathrm{~mm}$; wider than long: $\mathrm{aC} \approx 0.62 \mathrm{~b}_{\max } \mathrm{C}$; moderately convex tr. and sag., with gently curved anterior margin. Posterior margin of cephalon has distinct but small intergenal angle. Glabella moderately tapered forward with a slight constriction at L3; convex tr. and sag., strongly elevated above the interocular area, extraocular area and preglabellar area. Glabella occupies more than half of cephalic length (sag.): $\mathrm{aG} \approx 0.58 \mathrm{aC}$. LA occupies $23-25 \%$ of glabellar length (sag.). Anterior margin of glabella bluntly rounded at contact with preglabellar field. Sagittal profile of glabella is evenly arched: anterior and posterior arc segments have the same curvature and length, with its highest point at mid-L3. Transverse profile of glabella steeply arched, but not angular. Three pairs of glabellar furrows. S1 longest, widest and deepest, being directed obliquely backward and not reaching axis of glabella. S2 much shorter and shallower than S1, and also obliquely backward directed. S3 shortest, weakly incised, and have the form of moderate pits elongating obliquely forward. Axial furrow poorly impressed in the form of shallow, rather elongated pits at junction of S1 and S2 and interocular area, extremely weak opposite to LA. All four glabellar lobes are approximately equal in length (sag.), L3 is slightly longer than others. Occipital furrow distinct and deep, wide, a little 


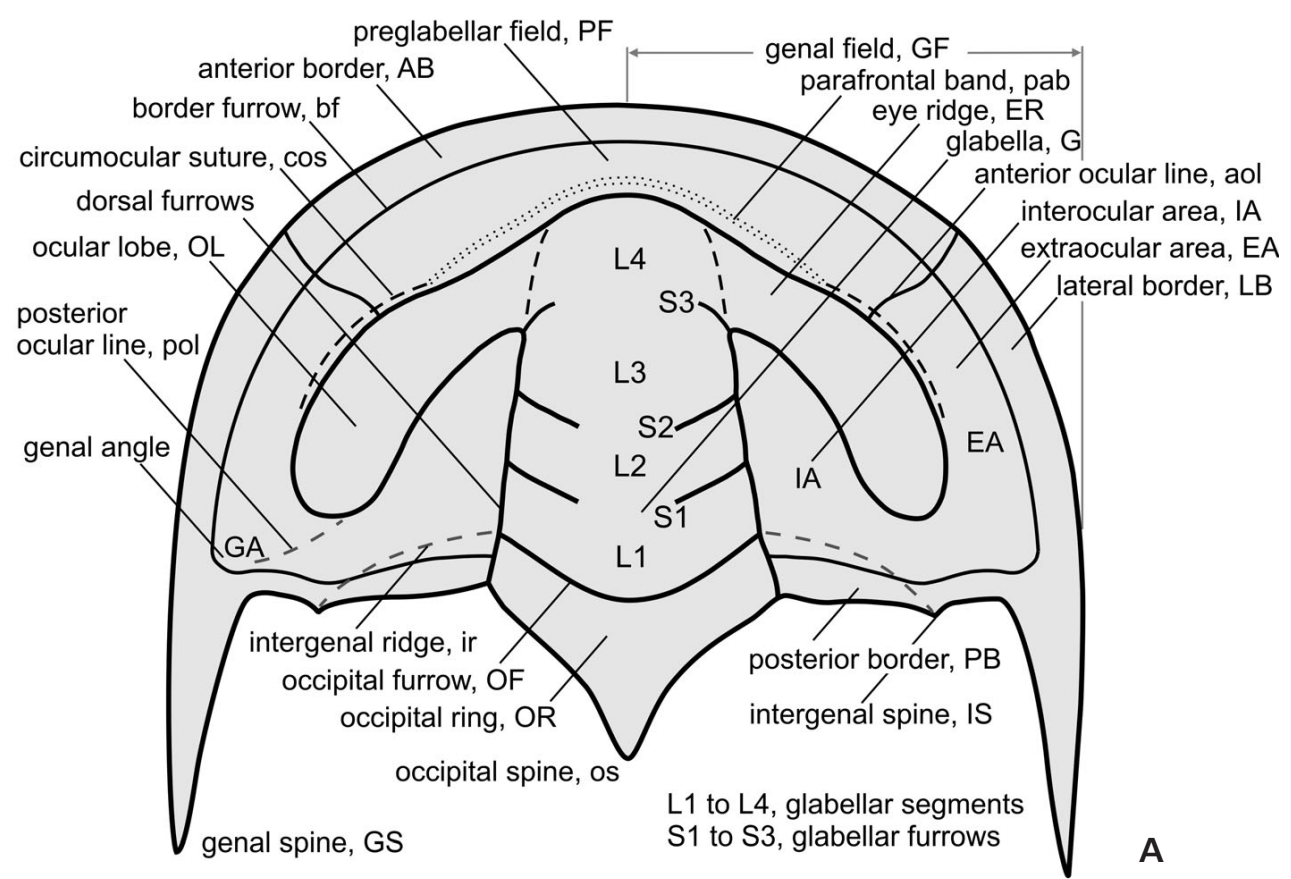

Figure 6. A - nomenclature for parts of the cephalon of Fallotaspidoidea. $\bullet \mathrm{B}-$ general dimensions of the cephalon.

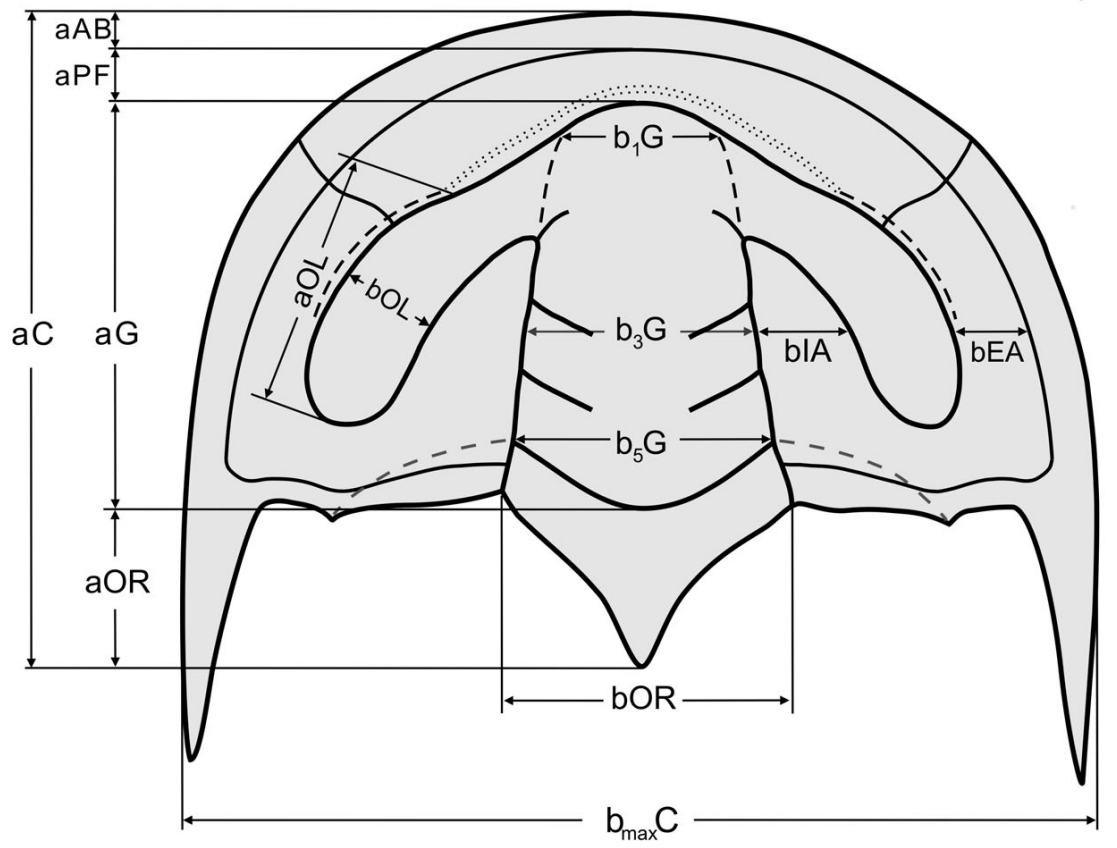

deeper and wider than S1 abaxially, strongly curved back, transglabellar.

Occipital ring slightly wider (tr.) than L1, convex, moderately long (sag.): $\mathrm{aOR} \approx 0.33 \mathrm{aG}$; with rounded triangular outline; elongated posteriorly into a moderately long, broad occipital spine, strongly elevated above L1. Highest point of occipital ring located at rear end of spine, a little higher than the highest point of glabella. Preglabellar field is short (sag.): $\mathrm{aPF} \approx 0.24 \mathrm{aG}$, moderately wide, concave or slightly flattened opposite axis of glabella, at anterolateral corners of glabella there are small elongated depressions. Preglabellar field rises distinctly anterior to ocular lobes.
Border furrow shallow, wide, smoothly arched between the preglabellar field and anterior border; at lateral border becoming barely evident, and merging with genal field at genal angle. Anterior and lateral border slightly convex, flattened, narrow (sag.): $\mathrm{aAB} \approx 0.08 \mathrm{aG}$. Lateral border merges with genal field near genal angle to form moderately long genal spine, apparent in specimen No. 2046/2, $\mathrm{aGS} \approx 0.3 \mathrm{aG}$ (sag.). Anterior border tilted back and slightly elevated at axis; lateral border slightly more arched than anterior border. Surface between lateral border and extraocular area considerably less relief than that between anterior border and preglabellar field. Highest point of an- 
terior border much lower than that of glabella. Extraocular and interocular areas of approximately equal width: $\mathrm{bEA} \approx 0.95 \mathrm{bIA}$. Interocular area subtriangular, moderately wide (tr.): $\mathrm{bIA} \approx 0.56 \mathrm{~b}_{3} \mathrm{G}$, flattened or very slightly convex. It possesses small depressions at the anterior corners between extraocular area and glabella and is tilted laterally and backwards. Extraocular area strongly tilted laterally and backwards to genal angle. Ocular lobes dorsally convex (tr.), highly elevated above genal field, slightly curved, long: $\mathrm{aOL} \approx 0.52 \mathrm{aG}$, moderately wide (tr.): $\mathrm{bOL} \approx 0.34 \mathrm{~b}_{3} \mathrm{G}$, gradually merging with eye ridges. Posterior tips of ocular lobes opposite midlength L1, do not reach posterior border. Eye ridges slightly less convex and less elevated than ocular lobes, gradually lower to LA, adjacent to anterolateral margin of LA at an angle of about $70^{\circ}$ from sagittal axis. The highest points of ocular lobes located at anterior margin, at confluence with eye ridges and much lower than the highest point of glabella. Distinct circumocular sutures at anterior margin of eye ridges adjoin to thin parafrontal band extending around anterior margin of glabella. Posterior border furrow shallow, deepening near occipital ring; poorly discernible, wide, with a pair of rounded pits opposite base of intergenal spine. Posterior border near occipital ring dorsally convex, slightly wider (sag.) than anterior border, narrow and flattened towards outer margins of cephalon; approximately midway between axial furrow and genal spine lies distinct but small geniculation with small intergenal spine on posterior border. Posterior border is directed obliquely backward from occipital ring to intergenal spine; from intergenal spine to genal spine it is directed slightly forward. On rear areas of genal field are narrow intergenal ridges $0.2-0.3 \mathrm{~mm}$ thick, originating from lateral margins of occipital furrow and directed obliquely outward and backward to intergenal spine. On extraocular area there is a pair of distinct thin well-impressed "facial lines" (possibly also taphonomic fractures), which begin where ocular lobes merges with eye ridges and trend, curving in a wave-like form, obliquely forward across anterior border to the cephalic margin. We interpret these to be biological structures and to represent weakening of the exoskeleton. We propose that these are incipient facial sutures, but that they have not developed completely, and are questionably homologous to the anterior ocular lines described in some other olenellids. In two of the specimens (2046/1 and 2046/2), these lines or sutures are identical, including their initial points of origin and direction, and they are symmetric along the sagittal axis. However, similar lines (fractures) behind the ocular lobes are absent.

The cephalic surface is covered in a system of raised ridges, intersecting to form a network of fine polygons with diameters up to $0.05 \mathrm{~mm}$. On elevated elements of the cephalon (glabella, occipital ring, ocular lobes, eye ridges and anterior border) this polygonal texture is minute, but

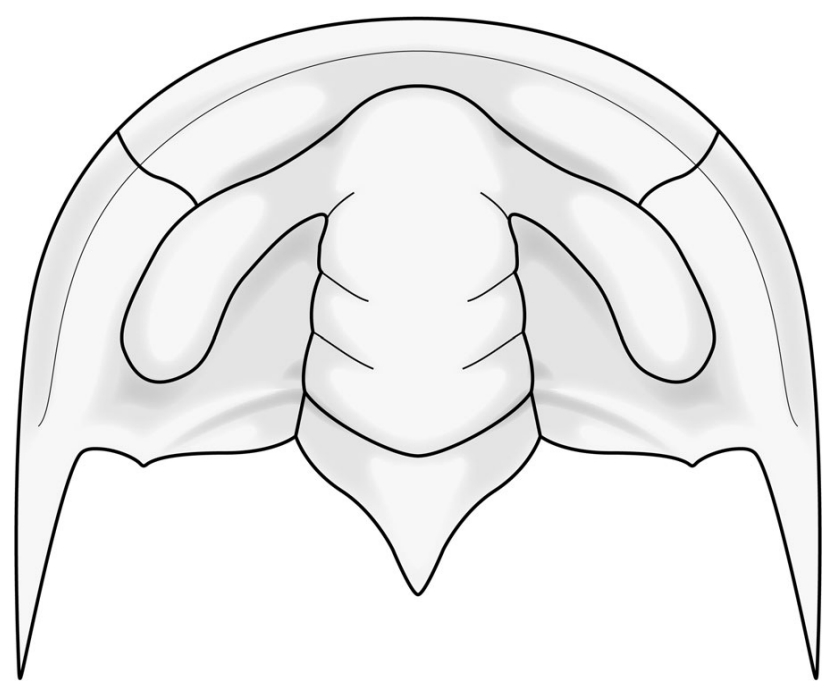

Figure 7. Reconstruction of the cephalon of Profallotaspis tyusserica Bushuev \& Goryaeva sp. nov., based on specimens CSGM No. 2046/1, 2046/2, 2046/5, Cambrian Stage 3, Lena River, northeastern Siberian Platform. Drawing digitised by L. Laibl.

on lower areas (preglabellar field, interocular area, extraocular area, posterior border) it is large and well-developed; polygonal texture becomes finer from central part to lateral edges of cephalon.

Measurements (mm). -

Holotype 2046/1: $\mathrm{aC}>8.5 ; \mathrm{aG}=5.05 ; \mathrm{aOR}>1.5 ; \mathrm{aPF}=1.2$; $\mathrm{aAB}=0.4 ; \mathrm{aOL}=2.6 ; \mathrm{b}_{\max } \mathrm{C}=14.6 ; \mathrm{bIA}=1.9 ; \mathrm{bEA}=1.8$; $\mathrm{b}_{1} \mathrm{G}=2.5 ; \mathrm{b}_{2} \mathrm{G}=3.2 ; \mathrm{b}_{3} \mathrm{G}=3.5 ; \mathrm{bOL}=1.15$.

Specimen 2046/2: $\mathrm{aC}>7.5 ; \mathrm{aG}=4.35 ; \mathrm{aOR}>1.5 ; \mathrm{aPF}=0.95$; $\mathrm{aAB}=0.35 ; \mathrm{aOL}=2.3 ; \mathrm{b}_{\max } \mathrm{C}=12.7 ; \mathrm{bIA}=1.6 ; \mathrm{bEA}=1.5$; $\mathrm{b}_{1} \mathrm{G}=2.2 ; \mathrm{b}_{2} \mathrm{G}=2.6 ; \mathrm{b}_{3} \mathrm{G}=2.9 ; \mathrm{bOL}=0.9$.

Specimen 2046/4: $\mathrm{aC}>5.1 ; \mathrm{aG}=2.9 ; \mathrm{aOR}>1.1 ; \mathrm{aPF}=0.7$; $\mathrm{aAB}=0.2 ; \mathrm{aOL}=1.6 ; \mathrm{bIA}=1.05 ; \mathrm{b}_{1} \mathrm{G}=1.5 ; \mathrm{b}_{2} \mathrm{G}=1.7 ; \mathrm{b}_{3} \mathrm{G}=1.9$; $\mathrm{bOL}=0.6$.

Specimen 2046/3: $\mathrm{aC}>7.8 ; \mathrm{aG}=4.7 ; \mathrm{aOR}>1.2 ; \mathrm{aPF}=1.1$; $\mathrm{aAB}=0.4 ; \mathrm{aOL}=2.5 ; \mathrm{bIA}=1.7 ; \mathrm{b}_{1} \mathrm{G}=2.3 ; \mathrm{b}_{2} \mathrm{G}=2.8 ; \mathrm{b}_{3} \mathrm{G}=3.2$.

Specimen 2046/5: $\mathrm{aC}>9.5 ; \mathrm{aG}=5.9 ; \mathrm{aOR}>2.3 ; \mathrm{aOL}>3.2$; $\mathrm{b}_{\max } \mathrm{C}>14.5 ; \mathrm{bIA}=2.1 ; \mathrm{b}_{1} \mathrm{G}=2.7 ; \mathrm{b}_{2} \mathrm{G}=3.5 ; \mathrm{b}_{3} \mathrm{G}=3.8$; $\mathrm{bOL}=1.4$.

Comparison. - The new species differs from the type species $P$. jakutensis Repina, 1965 (in Khomentovskiy \& Repina 1965 , p. 110) from the Pestrotsvet Formation on the middle reaches of the Lena River (southeastern Siberian Platform) in the following features:

Anterior margin of cephalon gently curved, whereas in $P$. jakutensis it is more strongly curved; preglabellar field 
concave or slightly concave, whereas in $P$. jakutensis it is slightly convex; anterior border is upraised, and tilted back, but in P. jakutensis it is slightly tilted forward; ocular lobes are slightly narrower, more oblique backward and almost extend to glabella; glabella is more convex, its sagittal profile is arched more steeply than that of $P$. jakutensis; glabella moderately tapered forward, whereas in $P$. jakutensis it is either parallel-sided or very slightly narrowed; S1 and S2 are directed obliquely backward, whereas in $P$. jakutensis they are almost transverse; depressions at the front angles of interocular area less distinct and deep than that of $P$. jakutensis; the relative width of interocular area is less than that of $P$. jakutensis; occipital ring elongates backwards to the moderately long, broad-based occipital spine, elevated above L1, whereas in P. jakutensis there is almost no occipital spine, but rather a posteriorly directed node; Occipital furrow strongly curved back, deeper and reaches the axis, whereas in $P$. jakutensis it is almost direct and shallow in the mid-part; posterior margin of cephalon has distinct intergenal angle at the intergenal spine, whereas in $P$. jakutensis it is straight or slightly backswept; intergenal spines on the posterior border are distinct, whereas in $P$. jakutensis they are reduced to dorsal swellings on the border; cephalon is proportionally wider than that of $P$. jakutensis; polygons formed by network of raised ridges are larger and more distinct, differentiated on elevated and lower areas.

The new species differs from Profallotaspis privica Repina, 1965 (in Khomentovskiy \& Repina 1965, p. 112) in the Pestrotsvet Formation of the Lena River (southeastern Siberian Platform) in having a more convex cephalon and glabella; three deeper pairs of glabellar furrows and deep occipital furrow; a flattened anterior border that is tilted back; a longer and concave preglabellar field, a dorsoposteriorly projecting occipital spine; a less robust ocular lobes and the different angle of their adjoining the glabella; well-impressed anterior "facial lines" directed obliquely forward; and a larger and more distinct polygonal network of raised ridges. In $P$. privica the glabella is slightly tapered forward with two pairs of weakly impressed furrows: S1 is inclined obliquely back and S2 begins behind the eye ridges; it is directed almost transverse to the axis. The preglabellar field in $P$. privica is flattened; the anterior and lateral border is generally slightly convex; occipital ring does not raise up; there is no occipital spine and weak anterior ocular lines (but not furrows) in $P$. privica, which do not cross anterior border and begin from the anterior tips of the ocular lobes.

Variability. - P. tyusserica sp. nov. exhibits variability in the impression of the glabellar furrows, in the curvature of the anterior margin of the cephalon, in the curvature of the glabellar anterior margin, in the degree of concavity of preglabellar field opposite the axis of the glabella, and in the degree of curvature of the posterior margin of the cephalon.

Remarks. - An occurrence of Profallotaspis? was tentatively identified in North America by J.S. Hollingsworth at the top of the Andrews Mountain of the Campito Formation in Esmeralda County, Nevada, in the Fritzaspis Zone of Cambrian Stage 3 (Hollingsworth 2007). The poor preservation of these specimens did not allow Hollingsworth to refer them with certainty to the genus Profallotaspis Repina. There is no doubt that these earliest trilobites belong to the Family Fallotaspididae Hupé, but photos of the Laurentian cephala demonstrate great differences from other species of the genus Profallotaspis: they exhibit a wide lateral border; strongly arched, long and narrow ocular lobes with the posterior tips opposite the posterior margin of the glabella; and a strongly curved anterior margin of the cephalon. A genal spine is not visible in the photographs. In our opinion, unambiguous assignment of Laurentian specimens to Profallotaspis will require further detailed studies in the Fritzaspis Zone.

Occurrence. - Northeastern Siberian Platform, Kharaulakh, the east bank of the Lena River, $350 \mathrm{~m}$ above the creek of Ulakhan-Aldyarkhai, middle member of the Tyusser Formation, section UA2, unit 10, Cambrian Stage 3, Profallotaspis Zone.

Family Nevadiidae Hupé, 1953

\section{Genus Nevadella Raw, 1936}

Type species. - Nevadella eucharis Walcott, 1913, Cambrian Stage 3, upper "Nevadella" Zone, Canada (Cordilleran region).

\section{Nevadella effusa Repina, 1974}

Figure 11D, E

1974 Nevadella effusa Repina, sp. nov.; Repina et al., pp. 104-105, pl. 25, figs 8-10, pl. 26, figs 1-4.

1982 Nevadella effusa Repina, 1974. - Repina, pl. 2, figs $7-10$.

Holotype. - Cephalon, CSGM, No. 452/38, Novosibirsk; Repina et al. (1974), pl. 25, fig. 8; the Lena River, Ulakhan-Aldyarkhai Creek, northeastern Siberian Platform, Russia, Cambrian Stage 3, Tyusser Formation, Pagetiellus anabarus-Nevadella Zone.

Material. - One moderately well preserved cephalon of medium and two other poorly preserved cephala. Specimens 


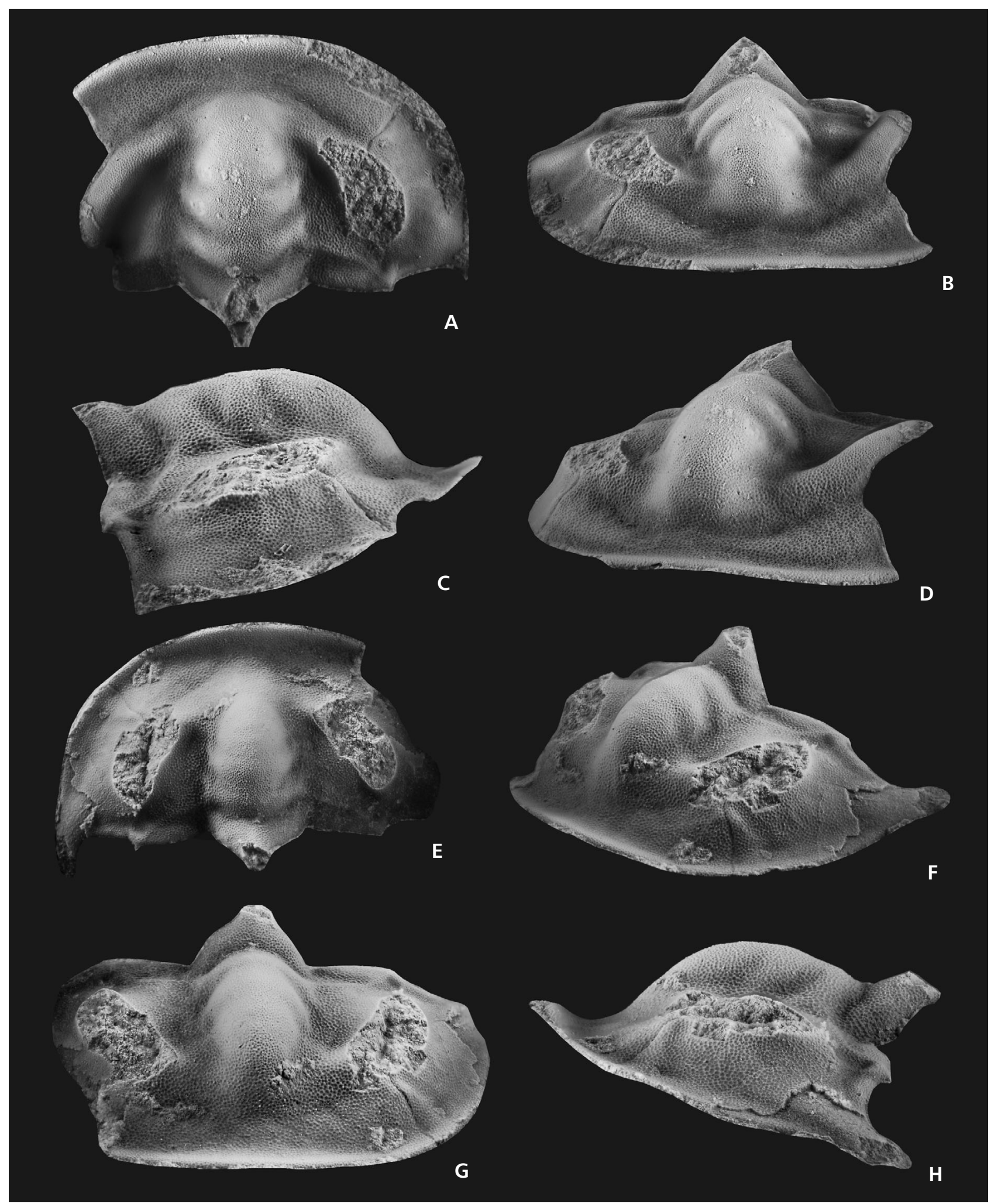

Figure 8. Profallotaspis tyusserica Bushuev \& Goryaeva sp. nov. • A-D - dorsal, anterior, lateral and oblique anterolateral views of holotype cephalon, CSGM 2046/1, × 6, Profallotaspis Zone, section UA2, unit 10, Ulakhan-Aldyarkhai Creek, Lena River. $\bullet \mathrm{E}-\mathrm{H}$ - dorsal, oblique anterolateral, anterior and lateral views of cephalon, CSGM 2046/2, × 5.5, from the same horizon. 
CSGM No. 2046/6, 2046/7, 2046/8. All material was collected together with Pagetiellus pervulgatus Laz. in gray and greenish-gray bioturbated, fine-medium-grained, blocky limestones, with ruffled fibrous and thinly-wavylaminated structure. All came from section UA2, the middle member of the Tyusser Formation.

Diagnosis. - Cephalon semicircular in outline, relatively wide. Glabella moderately tapering forward, conical, with slightly acuminate LA. Poorly expressed, slightly convex parafrontal band in front of glabella; plectrum sometimes present on preglabellar field. Ocular lobes long, curved; posterior tips opposite or slightly behind the occipital furrow. Interocular area narrow, less than half the width of glabella, opposite S1. Extraocular area moderately wide, slightly wider than L2, slightly convex, strongly tilted towards outer cephalic margins.

Description. - Cephalon small- to medium-sized, with semicircular outline, slightly extended in width, $\mathrm{aC} \approx 0.67 \mathrm{~b}_{\max } \mathrm{C}$, slightly convex, with curved anterior margin. Posterior margin of cephalon curved (concave anteriorly). Glabella evenly tapered forward, conical, slightly convex, slightly elevated above ocular lobes and genal field, more than half the length of $\mathrm{C}: \mathrm{aG} \approx 0.58 \mathrm{aC}$. Anterior margin of glabella slightly acuminate (strongly tapering LA) and smoothly sloping down to preglabellar field, does not reach anterior border. Glabella poorly defined anteriorly but with weak, slightly convex parafrontal band. Sagittal profile of glabella slightly curved with small deflections at S2 and S3. Highest point of glabella located approximately at center of its sagittal profile. Transverse profile of glabella is rounded. Three pairs of poorly defined, short, wide, indistinct glabellar furrows, transversely oriented. S1 and S2 forming marginal pits. S3 longest, practically transglabellar, but very shallow. Axial furrows poorly impressed, shallow, indistinct. $\mathrm{L} 1$ is longest, about 1/3 of glabellar length, $\mathrm{L} 2$ and L3 are shorter and about the same length; LA slightly longer than L3. Occipital furrow wide, much deeper and wider than S1, slightly arched backward. Occipital ring slightly wider than the base of glabella, comparable in length to L1; $\mathrm{aOR} \approx 0.28 \mathrm{aG}, \mathrm{bOR} \approx 1.05 \mathrm{~b}_{3} \mathrm{G}$, slightly convex, almost flat, with curved posterior margin, which bears small occipital node. Highest point of occipital ring located at posterior margin on occipital node, lower than highest point of glabella. Preglabellar field moderately long: $\mathrm{aPF} \approx 0.33 \mathrm{aG}$, flattened, with minor depressions before parafrontal band and in middle, along center-line of cephalon, where slightly convex, uneven plectrum sometimes present (absent on morphologically immature specimens). Border furrow as occipital furrow, deep, wide, becoming slightly shallower opposite posterior parts of the genal field, at genal angle it becomes quite shallow and indistinct. Anterior border very slightly convex, flattened, narrow: $\mathrm{aAB} \approx 0.11 \mathrm{aG}$, very slightly tilted back, getting narrower, passing into band-like lateral border. At the genal angle lateral border merges with wide and flat posterior border and forms short, backward directed genal spine. Highest point of anterior border much lower than summit of glabella. Interocular area narrow, elongate along glabella, bIA $\approx 0.44 \mathrm{~b}_{2} \mathrm{G}$, flattened, gradually sloping down to posterior border. Extraocular area moderately wide, slightly wider than L2 (tr.): $\mathrm{bEA} \approx 1.1 \mathrm{~b}_{2} \mathrm{G}$, slightly convex, strongly tilted laterally, posterior parts slightly tilted back. Genal angle elongated backward. Ocular lobes slightly convex, flattened, elevated above genal surface, curved, long: $\mathrm{aOL} \approx 0.89 \mathrm{aG}$; narrow, $\mathrm{bOL} \approx 0.33 \mathrm{~b}_{2} \mathrm{G}$; slightly tapered anteriorly. Anterior tips of ocular lobes adjacent approximately to middle of LA, in front of S3, at an acute angle. Posterior tips of ocular lobes located opposite to or slightly behind occipital furrow and almost reach posterior border. Highest point of ocular lobes located approximately at midlength, opposite to S2, much lower than summit of glabella, anterior and posterior ocular lobes segments slope slightly from central part. Distinct and shallow circumocular suture at outer margins of ocular lobes, adjoined anteriorly with slightly convex parafrontal band. Posterior border furrow indistinct and wide. Posterior border somewhat wider than lateral border, slightly convex, narrowing slightly toward outer edges of cephalon; directed obliquely backward from occipital ring to outer edges of cephalon. Small intergenal spines developed on posterior border midway between occipital ring and genal spine. Weak and narrow intergenal ridges, which begin from posterolateral corners of glabella and are directed obliquely backward through interocular area and posterior border to the intergenal spines. Cephalic surface has prosopon of very fine polygons that can be seen at $\times 40-50$ magnification. Some large fragmentary specimens show caeca on the preglabellar field.

\section{Measurements (mm).-}

Specimen 2046/6: $\mathrm{aC}=3.1 ; \mathrm{aG}=1.8 ; \mathrm{aOR}=0.5 ; \mathrm{aPF}=0.6$; $\mathrm{aAB}=0.2 ; \mathrm{aOL}=1.6 ; \mathrm{b}_{\max } \mathrm{C}=4.6 ; \mathrm{bIA}=0.4 ; \mathrm{bEA}=1.05$; $\mathrm{b}_{1} \mathrm{G}=0.6 ; \mathrm{b}_{2} \mathrm{G}=0.9 ; \mathrm{b}_{3} \mathrm{G}=1.05 ; \mathrm{bOL}=0.3$.

Comparison and remarks. - N. effusa differs from the type species Nevadella eucharis Walcott (1913, p. 315, pl. 53, fig. 1) in having a narrower and slightly more acuminate frontal lobe of the glabella, stronger proportional narrowing of glabella (N. eucharis has maximum narrowing in the areas of L1 and L2), longer ocular lobes, narrower and more strongly tilted outward extraocular area, narrower lateral border, and longer occipital ring. Nevadella effusa differs from the similar species N. faceta Fritz (1972, p. 23, pl. 3, figs 8-14) from the Sekwi Formation, Mackenzie Mountains in having a wider glabella at L2, less rounded LA, almost transverse shallow glabellar furrows (the ones 


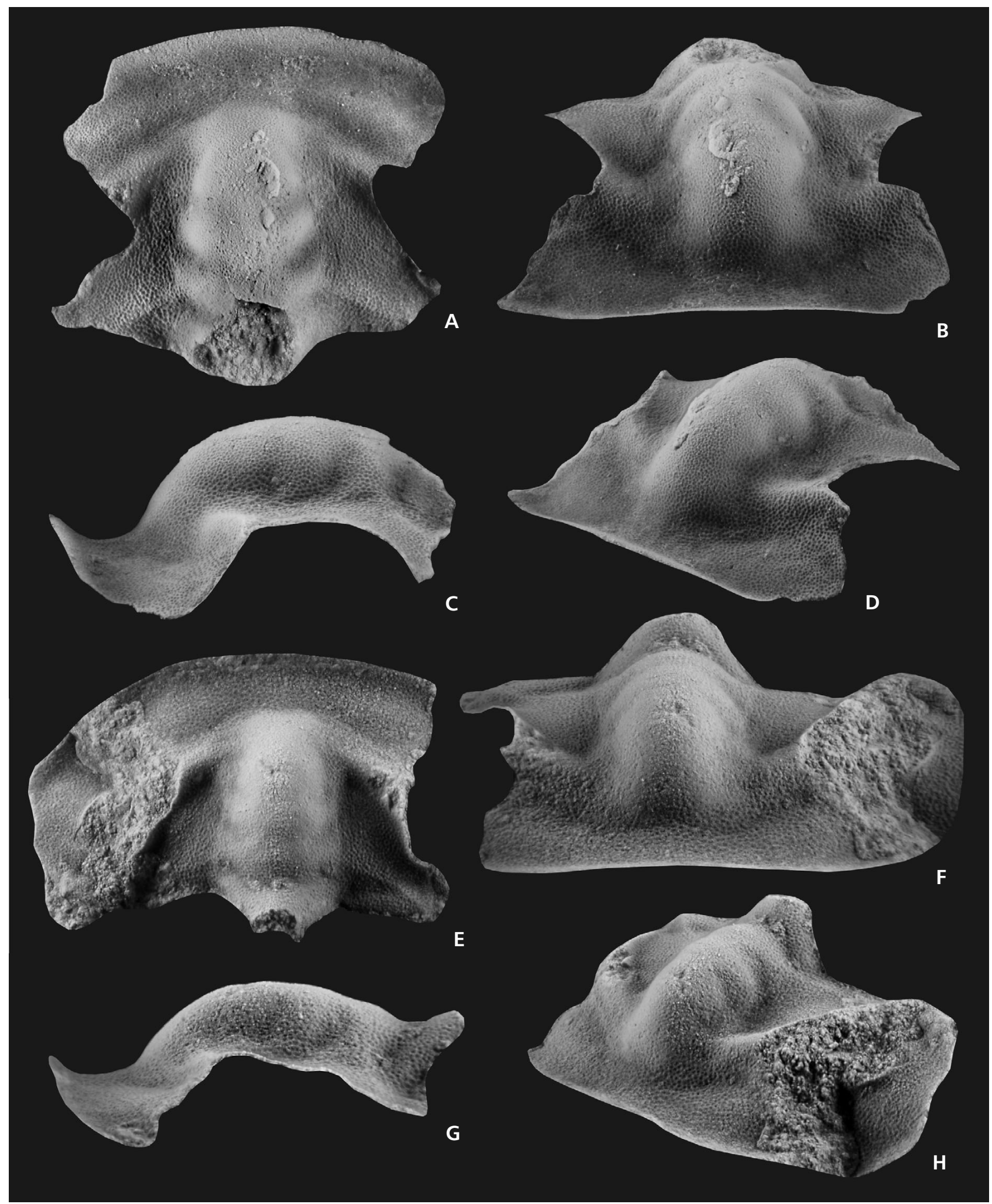

Figure 9. Profallotaspis tyusserica Bushuev \& Goryaeva sp. nov. $•$ A-D - dorsal, anterior, lateral and oblique anterolateral views of cephalon, CSGM 2046/3, × 10, Profallotaspis Zone, section UA2, unit 10, Ulakhan-Aldyarkhai Creek, Lena River. • E-H - dorsal, anterior, lateral and oblique anterolateral views of cephalon, CSGM 2046/4, × 8, Profallotaspis Zone, from the same horizon. 


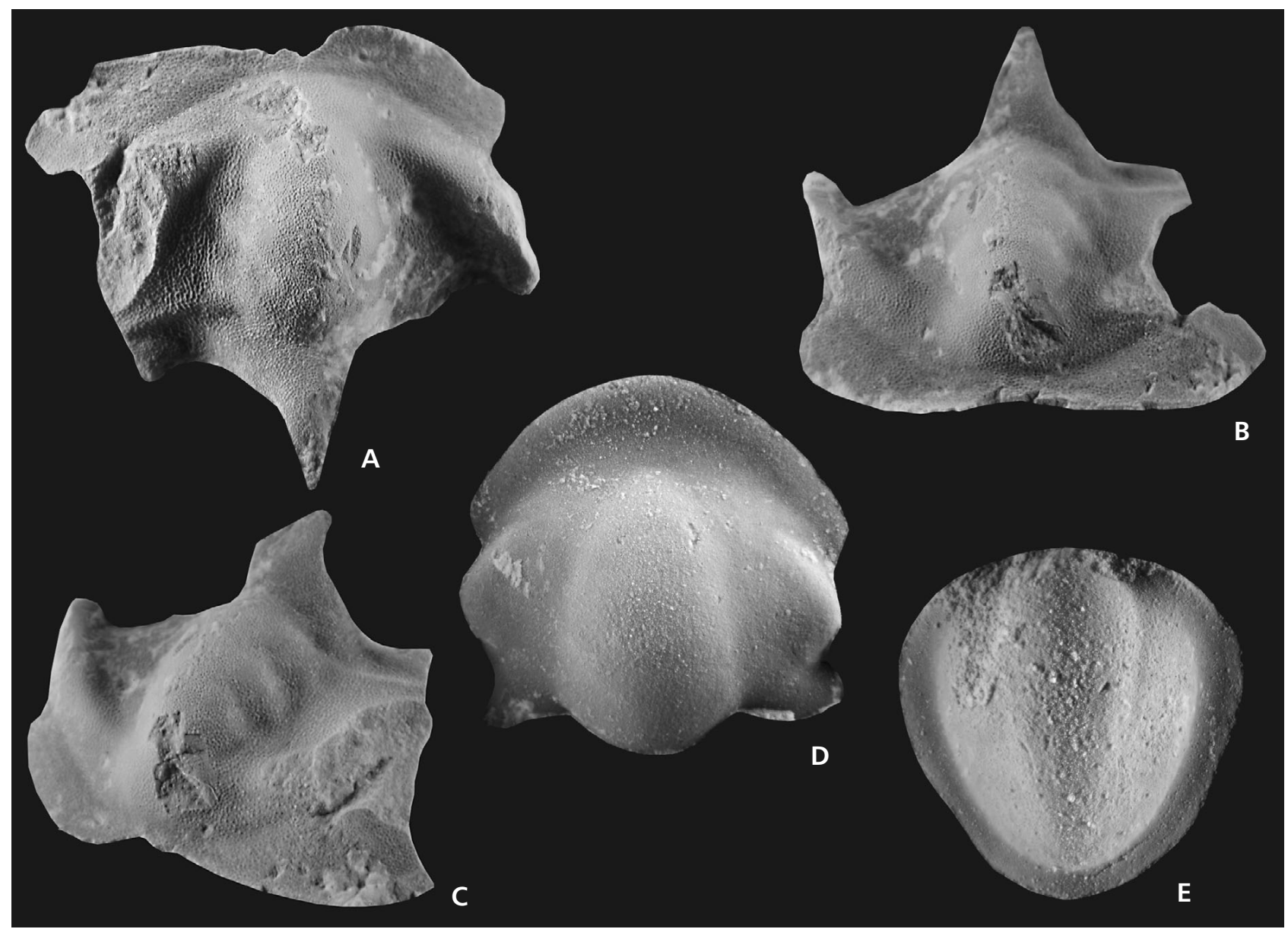

Figure 10. A-C-Profallotaspis tyusserica Bushuev \& Goryaeva sp. nov., dorsal, anterior, lateral and oblique anterolateral views of cephalon, CSGM 2046/5, × 6, Profallotaspis Zone, section UA2, unit 10, Ulakhan-Aldyarkhai Creek, Lena River. • D, E - Pagetiellus cf. anabarus Lazarenko, 1962; D - cranidium, CSGM 2046/12, × 15; E - pygidium, CSGM 2046/13, × 17, Pagetiellus anabarus-Nevadella Zone, section UA2, unit 16, Ulakhan-Aldyarkhai Creek, Lena River.

of $N$. faceta are deep near the axial furrow and are directed obliquely backward), extraocular area strongly tilted outward, narrower interocular area, less curved ocular lobes, longer occipital ring with arched posterior margin having a little node, as well as a less deep occipital furrow (the occipital furrow of $N$. faceta is very wide and deep near the axial furrow, and very shallow and indistinct sagittally).

Repina (in Palmer \& Repina, 1993) rejected the recognition of the Nevadella Zone in the traditional Lower Cambrian of the Siberian Platform and, most probably, reassigned the Kharaulakh specimens of effusa species to the genus Nevadia Walcott. We consider that because of the shape of the cephalon and the glabella, length and position of ocular lobes, width of extraocular area, the species effusa belongs to the genus Nevadella.

Occurrence. - Northeastern Siberian Platform, Kharaulakh, the east bank of the Lena River, $350 \mathrm{~m}$ above the Ulakhan-Aldyarkhai Creek, middle member of the Tyusser Formation, section UA2, unit 14 (occ. $14 \mathrm{c}$ from $1.5 \mathrm{~m}$ above the base of the unit), Cambrian Stage 3, Pagetiellus anabarus-Nevadella Zone.

Family Judomiidae Repina, 1979

\section{Genus Paranevadella Palmer \& Repina, 1993}

Type species. - Paedeumias? subgroenlandicus Repina, 1965 in Khomentovskiy \& Repina (1965), Cambrian Stage 3, the Pestrotsvet Formation, the Lena River, southeastern Siberian Platform.

\section{Paranevadella subgroenlandica \\ (Repina, 1965 in Khomentovskiy \& Repina 1965)}

Figure 11A-C

1965 Paedeumias? subgroenlandicus Repina, sp. nov.; Repina in Khomentovskiy \& Repina, pp. 121-122, pl. 3, figs $7-10$. 


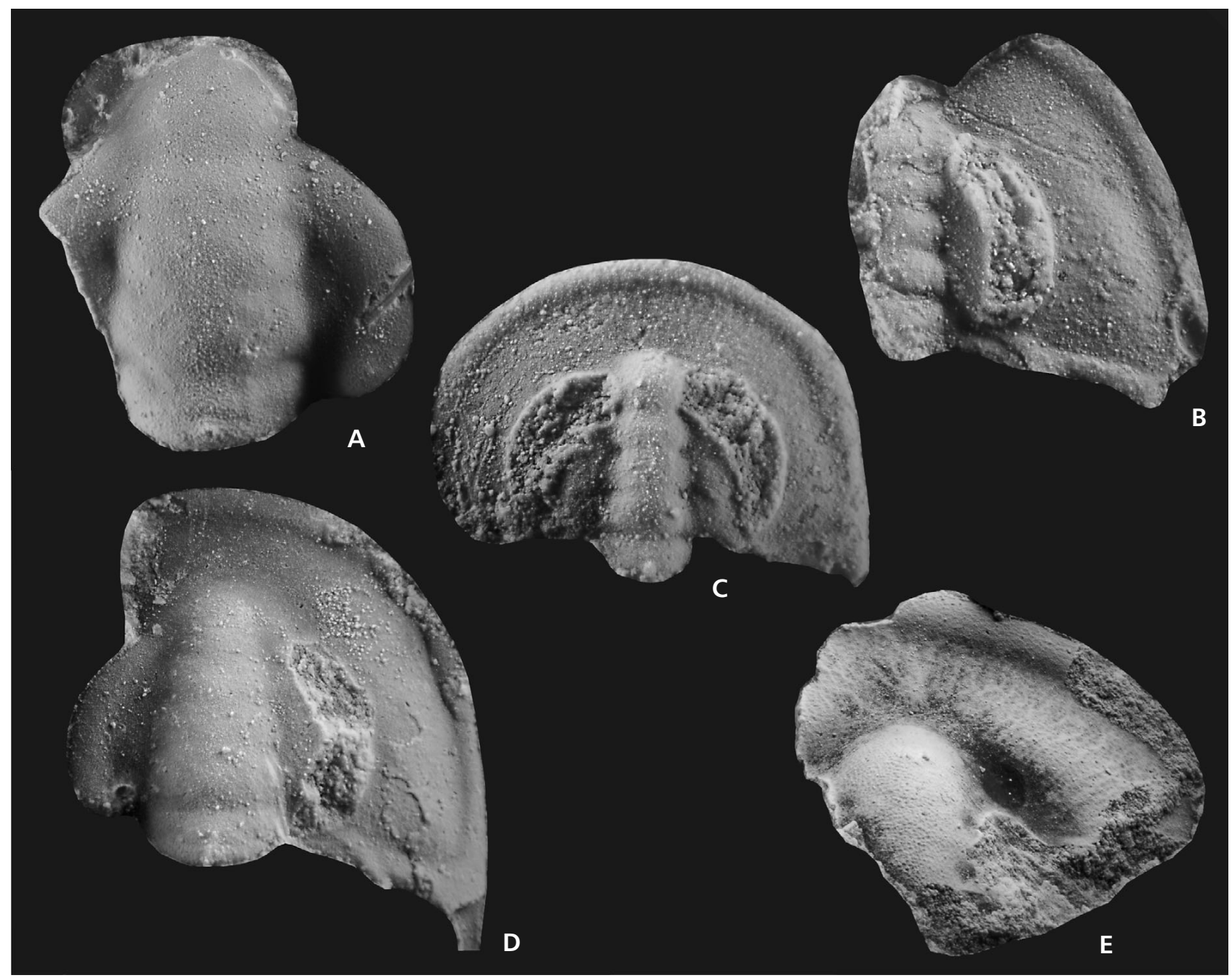

Figure 11. A-C-Paranevadella subgroenlandica (Repina, 1965 in Khomentovskiy \& Repina 1965); A - fragmentary cephalon, CSGM 2046/9, $\times 8$; B - fragmentary cephalon, CSGM 2046/10, × 12; C - meraspid cephalon, CSGM 2046/11, × 20, Pagetiellus anabarus-Nevadella Zone, section UA2, unit 16, Ulakhan-Aldyarkhai Creek, Lena River. $\bullet$ D, E - Nevadella effusa Repina, 1974; D - fragmentary cephalon, CSGM 2046/6, × 15; E - fragmentary cephalon, CSGM 2046/7, × 9, Pagetiellus anabarus-Nevadella Zone, section UA2, unit 14, from the same horizon.

1974 Paedeumias? aff. subgroenlandicus Repina, 1965. Repina et al., p. 103, pl. 25, figs 6, 7.

1983 Nevadella subgroenlandica (Repina, 1965). - Jegorova et al., p. 110, pl. 39, fig. 2.

1993 Paranevadella subgroenlandicus Repina, 1965. Palmer \& Repina, fig. 10.4.

Holotype. - Cephalon, CSGM, No. 265/174, Novosibirsk; figured by Repina, 1965 in Khomentovskiy \& Repina (1965), pl. 3, fig. 8; the Lena River, southeastern Siberian Platform, Cambrian Stage 3, upper Pagetiellus anabarus-Nevadella Zone.

Material. - One well preserved cephalon and three reasonably well preserved cephala. Specimens CSGM No. 2046/10, 2046/11, 2046/9. All material occurs in fine-medium-grained bioclastic, medium-thick-tabulate limestone, with knobby bedding surface (unit 16). All specimens came from section UA2, the middle member of the Tyusser Formation.

Diagnosis. - Cephalon sub-semicircular in outline, slightly transversely elongate. Glabella subcylindrical, slightly tapered forward, with rounded LA; three pairs of short glabellar furrows, dividing glabella into a long LA and three similar posterior lobes. Ocular lobes long, curved, located close to glabella; posterior tips opposite middle of occipital ring. Interocular area very narrow, flat, with distinct depressions at anterior corners between ocular lobes and glabella. Extraocular area moderately wide, comparable in width to L1, slightly convex, tilted laterally, with genal angle elongated backwards.

Description. - Cephalon medium-sized, sub-semicircular in outline, transversely elongate, $\mathrm{aC} \approx 0.7-0.8 \mathrm{~b}_{\max } \mathrm{C}$, 
slightly convex, with arched anterior margin and concave posterior margin. Glabella subcylindrical, slightly tapered forward, with rounded LA, slightly convex, elevated over surface of the genal field and ocular lobes, long: $\mathrm{aG} \approx 0.6 \mathrm{aC}$. Anterior margin of glabella slopes moderately steeply down to preglabellar field, does not reach anterior border. Anterior part of glabella well defined. Sagittal profile of glabella slightly arched evenly with small depression at S3. Glabellar high point approximately in middle of sagittal profile, adjacent to S2. Transverse profile of glabella slightly arched, not angular. Three pairs of lateral glabellar furrows. S1 deepest and widest, short and obliquely directed backwards; sides of glabella opposite S1 are slightly compressed and depressed. S2 less deep and shorter than $\mathrm{S} 1$, indistinct, shallow pits near axial furrow. S3 shallow, broad, indistinct, continuous, merging with axial furrow. Axial furrows poorly impressed, represented as a break in slope of axial part of the cephalon. L1, L2 and L3 approximately equal in length, $\mathrm{aL} 1 \approx 0.2 \mathrm{aG} \approx 1.0 \mathrm{aOR}$, and $\mathrm{LA}$ as almost twice as long, aLA $\approx 0.37 \mathrm{aG}$. Occipital furrow wide, deep on each side of occipital ring, considerably deeper than S1, slightly curved back, indistinct axially, shallow and wide. Occipital ring slightly wider than L1, not long, $\mathrm{aOR} \approx 0.21 \mathrm{aG}$, slightly convex, with curved posterior margin and distinct occipital node, somewhat offset from posterior margin of occipital ring. Highest point of occipital ring situated on occipital node, which is lower than summit of glabella. Preglabellar field moderately long, almost flat; morphologically immature specimens (probably meraspid cephalon, spec. 2046/11, Fig. 10C) are characterized by slight sagittal depression between anterior margin of glabella and anterior border, but without plectrum. Anterior border furrow wide, shallow along whole length, smaller than occipital furrow; slightly deeper anteriorly, fades near genal angle. Lateral border moderately convex dorsally, narrow: $\mathrm{bLB} \approx 0.5 \mathrm{aOR}$; slightly extending back; anterior border moderately curved. Genal spines absent. Interocular area narrow, bIA $\approx 0.26 \mathrm{~b}_{2} \mathrm{G}$; extraocular area moderately wide, $b E A \approx 1.0 \mathrm{~b}_{2} \mathrm{G}$. Interocular area with distinct depressions at the front angles between ocular lobes and glabella; gradually lower back and sideways to ocular lobes. Extraocular areas slightly convex, slightly tilted sideways, with genal angles elongated backwards. Ocular lobes located close to glabella, slightly convex, strongly curved, slightly elevated above genal field, long: $\mathrm{aOL} \approx 0.74 \mathrm{aG}$; narrow, $\mathrm{bOL} \approx 0.32 \mathrm{~b}_{2} \mathrm{G}$, slightly expanded to the anterior tips. Eye ridges absent. Anterior tips of ocular lobes adjacent to glabella at an acute angle in S3 area (to posterior margin of LA). Posterior tips of ocular lobes located opposite centre of occipital ring and almost reach posterior border. Highest point of ocular lobes near their anterior tips, a little lower than summit of glabella. Ocular lobes generally slightly tilted back. Posterior border furrow wide, slightly shallower than anterior border furrow. Posterior border narrow, much narrower than lateral border, slightly convex, somewhat widening (exsag.) from occipital ring to outer margins of cephalon; from occipital ring it is directed obliquely backward. Behind ocular lobes are weak, indistinct, and narrow intergenal ridges, diverging obliquely back toward posterior border. Anterior and posterior ocular lines are not observed. The largest specimens have cephalic surface with evenly spaced uniform small depressions.

\section{Measurements (mm). -}

Specimen 2046/9: $\mathrm{aC}>5.5 ; \mathrm{aG}=3.8 ; \mathrm{aOR}=0.8 ; \mathrm{aOL}=2.8$; $\mathrm{b}_{\max } \mathrm{C}>7.0 ; \mathrm{bIA}=0.5 ; \mathrm{b}_{1} \mathrm{G}=1.7 ; \mathrm{b}_{2} \mathrm{G}=1.9 ; \mathrm{b}_{3} \mathrm{G}=2.1 ; \mathrm{bOL}=0.6$.

Specimen 2046/11: $\mathrm{aC}=1.9 ; \mathrm{aG}=1.05 ; \mathrm{aOR}=0.2$; $\mathrm{aPF}=0.45 ; \mathrm{aAB}=0.15 ; \mathrm{aOL}=0.8 ; \mathrm{b}_{\max } \mathrm{C}=2.3 ; \mathrm{bIA}=0.2 ;$ $\mathrm{bEA}=0.4 ; \mathrm{b}_{1} \mathrm{G}=0.3 ; \mathrm{b}_{2} \mathrm{G}=0.35 ; \mathrm{b}_{3} \mathrm{G}=0.4 ; \mathrm{bOL}=0.2$.

Specimen 2046/10: $\mathrm{aC}>3.6 ; \mathrm{aG}=2.1 ; \mathrm{aOL}=2.0 ; \mathrm{b}_{\max } \mathrm{C}=5.6$; $\mathrm{bIA}=0.45 ; \mathrm{bEA}=0.9 ; \mathrm{bOL}=0.5$.

Occurrence. - Northeastern and southeastern Siberian Platform, Kharaulakh, on the east bank of the Lena River, $350 \mathrm{~m}$ above the Ulakhan-Aldyarkhai Creek, section UA2, occurrence $16 \mathrm{~b}$ from $1.6 \mathrm{~m}$ above the base of unit, occurrence $16 \mathrm{f}$ from $3.2 \mathrm{~m}$ below the top of unit, occurrence $16 \mathrm{~h}$ from $1.7 \mathrm{~m}$ below the top of unit, together with Pagetiellus cf. anabarus Lazarenko, Pagetiellus sp., Pagetiellus sakhaicus Nikiforov, Nevadella sp.; Cambrian Stage 3, Pagetiellus anabarus-Nevadella Zone.

\section{Conclusions}

New findings of trilobites Profallotaspis Repina, 1965 (in Khomentovskiy \& Repina 1965), Nevadella Raw, 1936 and Paranevadella Palmer \& Repina, 1993 in the north-eastern Siberian Platform have extended their distribution area and are of great importance for regional and international correlation. For now, Profallotaspis tyusserica sp. nov. is the most ancient trilobite in Siberia and possibly all over the world. We agree with the suggestion of Hollingsworth (2011) that the earliest trilobites in the world appeared nearly simultaneously in Siberia, Laurentia and Northern Gondwana (Morocco).

Profallotaspis tyusserica sp. nov., although an olenellid, is characterised, among other features, by the "facial lines" that are possible incipient facial sutures, present anteriorly of ocular lobes and crossing the anterior margin of the cephalon. The importance of this feature for further interpretations of early evolution in trilobites is that in our opinion the newly observed "facial 
lines" in this species are only questionably homologous to the anterior ocular lines in some other olenellids. These incipient facial sutures are a more primitive character in trilobites that had another function than the anterior ocular lines, so we do not share the conclusion about these structures being secondarily ankylosed facial sutures as proposed in other olenellids (Harrington 1959, O61-O63). Our argument is based on the presence of these incipient facial sutures in the oldest trilobites on the Siberian platform.

\section{Acknowledgements}

The authors express gratitude and acknowledgement to A.I. Varlamov and A.V. Rosova for assistance in arrangements for expedition, as well as for consultations and kind advice. We also would like to thank T.V. Pegel for valuable consultations and M.V. Zhurba for help and enthusiasm in the collection of the fossil material. This manuscript was improved by helpful formal reviews from N. Hughes, M. Webster and an anonymous reviewer, we are gratefully acknowledged to them. We particularly thank P. Budil for detailed discussion of conclusions and we are also grateful to L. Laibl for the digitization of a pencil drawing reconstruction.

\section{References}

ANONYMOUs 1983. Resheniya Vsesoyuznogo stratigraficheskogo soveshchaniya po dokembriyu, paleozoyu i chetvertichnoy sisteme Sredney Sibiri [Resolution of All-Union Stratigraphic Meeting on the Precambrian, Palaeozoic and Quarternary System of Middle Siberia]. Part I (Upper Precambrian and Lower Palaeozoic). 216 pp. Siberian Research Institute of Geology, Geophysics and Mineral Resources Press, Novosibirsk. [in Russian]

Astashkin, V.A., Pegel, T.V., Repina, L.N., Rozanov, A.Y., Shabanov, Y.Y., Zhuravlev, A.Y., Sukhov, S.S. \& SunduKov, V.M. 1991. The Cambrian System on the Siberian Platform. Correlation chart and explanatory notes. International Union of Geological Sciences Publication 27, 1-133.

Bengtson, S., Conway Morris, S., Cooper, B.J., Jell, P.A. \& Runnegar, B.N. 1990. Early Cambrian fossils from South Australia. Memoirs of the Association of Australasian Palaeontologists 9, 1-364.

CobBold, E.S. 1935. A new genus of the Trilobita and a new species of the Conchostraca from the Cambrian of the Carteret region, N.W. France. Annals and Magazine of Natural History, Series 10(15), 381-392.

Egorova, L.I., Repina, L.N. \& Suvorova, N.P. 1983. Lower Cambrian stage subdivision of the Siberia. Atlas of fossils. Akademiya nauk SSSR, Sibirskoe otdelenie, Trudy Instituta geologii i geofiziki 558,1-216. [in Russian]

FRITZ, W.H. 1972. Lower Cambrian trilobites from the Sekwi Formation type section, Mackenzie Mountains, northwestern Canada. Geological Survey of Canada Bulletin 212, 1-90.
GeyER, G. 1996. The Moroccan fallotaspidid trilobites revisited. Beringeria 18, 89-199.

Harrington, H.J. 1959. Morphological terms applied to Trilobita, 117-126. In Moore, R.C. (ed.) Treatise on Invertebrate Palaeontology, Part O, Arthropoda 1. Geological Society of America \& University of Kansas Press, New York \& Lawrence.

Hollingsworth, J.S. 2007. Fallotaspidoid trilobite assemblage from the Esmeralda Basin (western Nevada, U.S.A.). Memoirs of the Australasian Association of Palaeontologists 32, 123-140.

HollingSwORTH, J.S. 2011. Lithostratigraphy and biostratigraphy of Cambrian Stage 3 in western Nevada and eastern California. Museum of Northern Arizona Bulletin 67, 26-42.

Hupé, P. 1953. Contribution à l'étude du Cambrien inférieur et du Précambrien III de l'Anti-Atlas marocain. Service géologique du Maroc, Notes et Mémoires 103, 1-402.

Jell, P.A. 2003. Phylogeny of Early Cambrian trilobites, 45-57. In Lane, P.D., Siveter, D.J. \& Fortey, R.A. (eds) Trilobites and their relatives, contributions from the Third International Conference, Oxford, 2001. Special Papers in Palaeontology 70.

Khomentovskiy, V.V. \& Repina, L.N. 1965. The Lower Cambrian stratotype section of Siberia. 199 pp. Akademiya nauk SSSR, Moscow. [in Russian]

LAZARENKO, N.P. 1962. New Lower Cambrian trilobites of the Soviet Arctic, 29-78. In Shvedov, N.A. (ed.) Trudy Nauchno-issledovatel'skogo instituta geologii Arktiki SSSR (NIIGA) 29. 92 pp. Leningrad. [in Russian]

Palmer, A.R. \& RePinA, L.N. 1993. Through a glass darkly: taxonomy, phylogeny and biostratigraphy of the Olenellina. University of Kansas Paleontological Contributions, New Series 3, 1-35.

Palmer, A.R. \& RepinA, L.N. 1997. Introduction to Suborder Olenellina, 405-428. In Moore, R.C. \& KAESLER, R.L. (eds) Treatise on Invertebrate Paleontology, Part O, Arthropoda 1, Trilobita, Revised. Geological Society of America \& University of Kansas Press, Boulder \& Lawrence.

Pillola, G.L. 1993. The Lower Cambrian trilobite Bigotina and allied genera. Palaeontology 36, 855-881.

RAw, F. 1936. Mesonacidae of Comley in Shropshire, with a discussion of classification within the family. Quarterly Journal of the Geological Society of London 92, 236-293. DOI 10.1144/GSL.JGS.1936.092.01-04.13

Repina, L.N., Lazarenko, N.P., Meshiova, N.P., Korshunov, V.I., NiKIFOROv, N.I. \& AKSARINA, N.A. 1974. Biostratigraphy and fauna of the Lower Cambrian of Kharaulakh (Tuora-Sis ridge), 1-299. In Sokolov, B.S. \& Repina, L.N. (eds) Akademiya nauk SSSR, Sibirskoe otdelenie, Trudy Instituta geologii i geofiziki 235. [in Russian]

REPINA, L.N. 1979. Dependence of morphologic features on habitat conditions in trilobites and evaluation of their significance for the systematics of the Superfamily Olenelloidea. Akademiya nauk SSSR, Sibirskoe otdelenie, Trudy Instituta geologii i geofiziki 431, 11-30. [in Russian]

REPINA, L.N. 1982. Ecotypes of trilobites Olenelloides, 46-60. In Betechtina, O.A. \& Zhuravleva, I.T. (eds) Sreda i zhizn' 
v geologicheskom proshlom. Paleolandshafty $i$ biofacii. Nauka, Novosibirsk. [in Russian]

REPINA, L.N. \& LutchininA, V.A. 1981. To the biostratigraphy of the lower part of the Cambrian in the northwestern Prianabarye (Fomich R.). Akademiya nauk SSSR, Sibirskoe otdelenie, Trudy Instituta geologii i geofiziki 475, 3-19. [in Russian]

SDZUY, K. 1978. The Precambrian-Cambrian boundary beds in Morocco (preliminary Report). Geological Magazine 115(2), 83-94. DOI 10.1017/S0016756800041133

Suvorova, N.P. 1960. Cambrian trilobites from the eastern Siberian Platform. Part 2: Olenellida-Granulariida. Trudy Paleontologicheskogo instituta, Akademiya nauk SSSR 84, 1-238. [in Russian]
WaLcotT, C.D. 1890. The fauna of the Lower Cambrian or Olenellus Zone. U.S. Geological Survey, $10^{\text {th }}$ Annual Report 1 , 509-760.

Walcott, C.D. 1913. Cambrian Geology and Paleontology, No. 11. New Lower Cambrian subfauna. Smithsonian Miscellaneous Collections 57, 309-326.

YUAN, J.L., Zhu, X.J., Lin, J.P. \& ZHU, M.Y. 2011. Tentative correlation of Cambrian Series 2 between South China and other continents. Bulletin of Geosciences 86(3), 397-404. DOI 10.3140/bull.geosci.1274

ZHANG, W.T. 1966. On the classification of Redlichiacea, with description of new families and genera. Acta Palaeontologica Sinica 14, 135-184. 